\title{
HERMENEUTICS OF RE-ENACTING BIBLICAL TEXT(S) AND CONCEPT(S) IN THE HISTORY OF PROPHETISM IN GHANA'S CHRISTIANITY: A CASE STUDY OF THE MINISTRY OF AGABUS AND PROPHET BERNARD OPOKU NSIAH
}

\section{Daniel Nii Aboagye Aryeh}

Biblical Studies Lecturer, School of Theology, Perez University College, Winneba Ghana danielniiaboagyearyeh@gmail.com

\section{ABSTRACT}

Biblical hermeneutics is significant in delineating the meaning of scripture text(s) for contemporary audiences. The critical historical method as well as its derivative criticisms is the widely used approach to understand what the text meant for the "original" audience in its sitz im leben. It is socio-historical in nature and curbs religious fundamentalism. However, its concentration on history does not make it suitable for prophetic ministries in Ghana. The approach to scripture interpretation by prophetic ministries since 1914 has been re-enactment of favourite scripture text(s) to have instructions for life in the present situation and the future. They believe that being biblical is the patterning of life style or activities along some popular characters in the Bible. Prophet Bernard Opoku Nsiah claims that his prophetic ministry is patterned or is a replica of the prophetic ministry of Agabus in the book of Acts. This essay examines biblical interpretation in the history of prophetism in Ghana's Christianity, and how scripture text(s) were used as hermeneutics of re-enactment.

Keywords: Appropriation; contextualisation; exegesis; hermeneutics; prophetism; re-enactment

\section{UNISA}

Studia Historiae Ecclesiasticae https://upjournals.co.za/index.php/SHE 


\section{INTRODUCTION}

The book of Acts and the epistles serve as motivations and examples of ministry patterns for prophetic ministries in Ghana. This is due to the fact that the book of Acts and the epistles generally recorded the ministry activities of the apostles and close allies of Jesus by the empowerment of the Holy Spirit. The appropriation of some text(s) in the book of Acts is grounded on their emphasis on pneumatological activities. In an interview with Prophet Opoku Nsiah, he claimed that his prophetic ministry is in agreement with and like-patterned to that of Agabus. This paper concerns itself with the questions: (i) What has been the hermeneutics of prophetic ministry in Ghana since 1914? (ii) What is the relationship between the ministry of Agabus and Prophet Opoku Nsiah? (iii) What are the hermeneutical consequences of prophetic ministries in Ghana? To achieve this goal, my procedure is to discuss the history of prophetism in Ghana's Christianity; examine the ministry of Agabus; discuss the ministry of Prophet Opoku Nsiah; discuss the hermeneutics of prophetic ministry in Ghana; amend and propose the composition of hermeneutics of reenactment; and draw conclusions.

Two methods are engaged in this study. (i) Historical narrative approach is adopted in order to give a comprehensive account of prophetism in Ghana's Christianity between 1914 and 2016. It is mainly a qualitative method involving library research, interviews, discussions, analysis, and interpretation of findings. (ii) Contextual approach is used to discuss texts that made reference to Agabus. W. Randolph Tate states that "in literary studies, context may refer to the materials and situations surrounding the writing or reading of a TEXT. These materials and situations are historical, cultural, geographical, ecclesiological, ideological, and literary." Contextual method in this essay considers the social, cultural, and religious background that influenced the production of narratives concerning Agabus, taking cognisance of these elements in delineating the passage for contemporary audiences.

\section{PHASES OF PROPHETISM IN GHANA}

\section{Phase 1}

In Ghana, the prophetic ministries of Prophets William Wadẻ Harris (c. 1860-1929), John Swatson (c.1855-c.1925), and Kwame Sampson Oppong (c.1884-c.1965) who were founders of African Independent/Initiated/Indigenous Churches (AICs) have attracted scholarly acceptance as forerunners of prophetic ministry or forerunners of Pentecostalism in Ghana. The AICs were also referred to as Sunsum sorè (spiritual

1 W. Randolph Tate, Handbook for Biblical Interpretation: An Essential Guide to Methods, Terms, and Concepts (Grand Rapids, Michigan: Baker Academic, 2012), 85. Italics and block words in original. 
churches); their liturgy and beliefs were similar to the Aladura Churches in Nigeria, and the Zionist Churches in South Africa. ${ }^{2}$ The Akan phrase, Sunsum sorè is ambiguous and lacks precision. Sunsum refers to spirit or being spiritual; sorè can be used to refer to two related phenomena: (i) It is derived from the word osore $\varepsilon$ (worship or adoration) as used in John 4:24 (Asante Twi version). (ii) It is also used to refer to a church (assre) or a Christian denomination. It is probable that scholars who use sorè refer to a Christian denomination. However, to be precise, asafo (church, assembly, gathering) is a better option to sorè as used in Matthew 16:18; 18:17; in the book of Acts; the epistles, and in the book of Revelation. Therefore, Sunsum asafo is better translated as spiritual church than Sunsum sorè. The names point to their emphasis on the activities of the Spirit in worship services, as antithesis to that of the Western-led missionary churches.

Phase 1 is popularly referred to as the emergence of prophetism in Ghana's Christianity. ${ }^{3}$ It started in Axim, and Apollonia in Nzima in 1914 by Prophet Harris ${ }^{4}$ and was later supported by Prophets Swatson and Oppong after being influenced by Prophet Harris. J. K. Asamoah-Gyadu postulates that this form of prophetism was partly a reaction "against the over-cerebral and rationalistic nature of Western forms of being Christian. The inability of Western Christianity to integrate Charismatic experiences, particularly healing and prophecy, into worship in Africa, led in time to the rise of a plethora of independent, indigenous church movements under various local charismatic figures." Ghanaian world-views such as language, dancing, among others, were used in Christian worship services in the midst of pneumatic activities. ${ }^{6}$ J. Annorbah-Sarpei asserts that the prophetic activities of these prophets curtailed the activities and popularity of Tigare shrines that were highly patronised in those days. ${ }^{7}$ In other words, they served as Christian alternative for Tigare shrines.

2 J. Kwabena Asamoah-Gyadu, African Charismatics: Current Developments within Independent Indigenous Pentecostalism in Ghana (Leiden, Koninklijke Brill NV, 2005), 21.

3 Joseph Quayesi-Amakye, "Let The Prophet Speak: A Study On Trends In Pentecostal Prophetism With Particular Reference To The Church Of Pentecost And Some Neo-Pentecostal Churches In Ghana" An MPhil Thesis submitted to the Department of Religion and Human Values of the Faculty of Arts, University of Cape Coast (July 2009), 55. See also Daniel Nii Aboagye Aryeh, "Socio-Rhetorical Exegesis of 1 Corinthians 14:26-40 for an Understanding of $\pi \rho \circ \varphi \eta \tau \eta$ in Pauline Corpus and its Implications for Contemporary Prophetic Ministry in Ghana" A Master of Theology Thesis submitted to Trinity Theological Seminary, Legon Ghana (May 2015), 77.

4 James Anquandah, "The Ghana Independent/Pentecostal Movement" in The Rise of Independent Churches in Ghana (Accra: Asempa Publishers, 1990), 22.

5 J. Kwabena Asamoah-Gyadu, "Pentecostalism and the Missiological Significance of Religious Experience in Africa Today: The Case for Ghana 'Church of Pentecost' in Trinity Journal of Church and Theology, Vol. XII, No 1\&2 (July/December 2002), 30-57.

6 Anquandah, "The Ghana Independent/Pentecostal”, 22.

7 James Annorbah-Sarpei, "The Rise of Prophetism - A Socio-Political Explanation" in The Rise of Independent Churches in Ghana (Accra: Asempa Publishers, 1990), 27, 30. 
Their activities were mainly concentrated in the rural areas. This may be due to the low level of education by their leaders or the desire to eradicate idol worship, which was more rampant in the rural areas. However, the pioneers of prophetism in Ghana's Christianity began to decline after about 50 years of existence and popularity. Research in 1986 and 1991 by Ghana Evangelism Committee (GEC), has shown that the AICs began declining in membership in the 1970s. ${ }^{8}$ There were three main reasons associated with their decline: derogatory remarks; charisma and succession; and hermeneutics. (i) P. Mwaura asserts that in view of their rootedness in African religio-cultural world-view, they were demonised by newer Pentecostal Churches. ${ }^{9}$ Simply put, they were derogated as ritualistic and occultic (ii) AsamoahGyadu postulates that in view of the fact that it was the charisma of the founders that attracted members, the death of a founder without commensurate replacement in the area of charisma contributed to the decline. ${ }^{10}$ (iii) Amevenku ${ }^{11}$ holds that leaders of the AICs perceive theological education as a form of Westernisation and therefore preferred a mentorship form of training over formal theological training. This relegated biblical interpretation to the popular level. Hence the primary purpose of hermeneutics, which sought to understand the original intended meaning of a passage and delineate it to contemporary audiences, was not followed.

The leaders of the AICs were not theologically trained readers of the Bible. They were ordinary readers of the Bible to empower and motivate faith in their audience for miracles or to solve existential needs. Using the local language versions of the Bible, they selected text(s) that have some parallels with the Ghanaian socioreligio-cultural settings without exegeting to find what the text meant to its "original" audience. It was contextualised and appropriated on the literal face. This art was popularly understood as being biblical. It is the selection of text(s) and practices in the Bible and its adaptation to produce solutions for existential issue. The interpretation of the text(s) was based on the personal experience of the leader/interpreter, which he/she claimed to have been received by the Holy Spirit. However, the canon of the Bible was highly respected among the AICs and treated as sacred. This is due to their rejections of critical reading and interpretation of the Bible.

Nevertheless, the contributions of the AICs to prophetism in Ghana's Christianity cannot be ignored. (i) The AICs considered gender issues in the clergy by involving women among the leaders of the church. The qualification was the exhibition of charisma. This has made way for women like Grace Tani to join the evangelistic

8 Frederick Mawusi Amevenku, "Mother Tongue Biblical Interpretation and the Future of African Instituted Christianity in Ghana" in Trinity Journal of Church and Theology Vol. 18, No. 1 (March 2014), 133-148.

9 Cited in Cephas N. Omenyo \& Abamfo O. Atiemo, "Claiming Religious Space: The Case of Neo-Prophetism in Ghana" in Ghana Bulletin of Theology, New Series Vol. 1, No. 1 (July 2006), 55-68.

10 Asamoah-Gyadu, African Charismatics, 65-66.

11 Amevenku, "Mother Tongue Biblical Interpretation" in TJCT, 138-142. 
team of Harris. ${ }^{12}$ (ii) They encouraged the use of indigenous mother tongue as the main lingua franca in Christian liturgy, hence the use of local choruses, drumming and spontaneous dancing in worship services. (iii) They encouraged pneumatic Christianity that led to provision of existential needs of worshipers. ${ }^{13}$

\section{Phase 2}

Neo-prophetism in Ghana started with the Classical Pentecostals (CPs) led by Apostle Peter Newman Enim (1890-1984). James McKeown, Gilbert Ablorh Lawson, and Prophet John Mensah were influential in this phase. Lawson and Mensah later formed the Divine Healers Church and Church of Christ (Spiritual Movement) respectively. ${ }^{14}$ This phase of prophetism emphasised divine healing. Too much has not been heard of this phase of prophetism. ${ }^{15}$ Scripture interpretation in this phase was also selective and directed towards this worldly hermeneutics. They selected text(s) that border on God's promise of healing and good health which were interpreted from the world-view of the leader and the audience. Healing events in the Bible were interpreted as proofs and examples for the leaders to exercise the gifts of healing and the audience (sick) to have faith to be healed.

\section{Phase 3}

Revival of Christian fellowships in tertiary institutions expressed a certain level of prophetism. A. O. Atiemo suggests that this prophetism was mostly found among students who had experienced the fellowship of the Scripture Union (SU) at the secondary school level. ${ }^{16}$ Reporting on prophetic activities of these fellowships at Kwame Nkrumah University of Science and Technology (KNUST), S. Adubofour postulates that "prophecy was the excitement of the day". ${ }^{17}$ Emphasis was placed on the prophet-hood of all believers. Although the leaders in this phase were quite educated and could read fluently in English, they were not theologically educated. Scripture interpretation was largely dependent on the experiences of the leader with the Holy Spirit, with emphasis on lexical meaning of some key words in the text(s)

12 Christian G. Baëta, Prophetism in Ghana: A Study of Some 'Spiritual' Churches (Accra: African Christian Press, 2004), 8.

13 For further discussion refer see Christian G. Baëta, Prophetism in Ghana: A Study of Some 'Spiritual' Churches (Accra: African Christian Press, 2004); The Rise of Independent Churches in Ghana (Accra: Asempa Publishers, 1990).

14 Aryeh, "Socio-Rhetorical Exegesis of 1 Corinthians 14:26-40", TTS, 74.

15 For further discussion on the ministry of Brother Lawson see Emmanuel Kingsley Larbi, Pentecostalism: The Eddies of Ghanaian Christianity (Accra: SAPC, 2001), 367-379.

16 Abamfo O. Atiemo, The Rise of the Charismatic Movement in the Mainline Churches in Ghana (Accra: Asempa Publishers, 1993), 30.

17 Cited in Quayesi-Amakye, "Let The Prophet Speak” UCC, 40. 
chosen. The Bible was believed to have been written with the concerns of 21st century Ghanaian Christians in mind.

\section{Phase 4}

The fourth phase of prophetism in Ghana's Christianity was vivid in the prayer camps of the Church of Pentecost (CoP). J. Quayesi-Amakye asserts that there were two kinds of prophets in the $\mathrm{CoP}:{ }^{18}$ (i) Grassroots prophets are untrained and not officially recognised by the church. (ii) Conversely, the official or institutionalised prophets are those trained and accepted by the church. These prophets have established prayer camps where they operate. Examples include Prophetess Grace Adu's Adumfa Prayer Camp located in the Central Region, and Mama Grace's Agape Prayer Camp located at Ablekuma in Accra. These prayer camps served as a place for seeking God's intervention in existential needs.

Prophets in this phase were either semi-literate or illiterate in English language, but they could read the version(s) of the Bible in local languages. Scripture interpretation was at the mercy of the prophetic gift of the leader. He/she quotes a scripture text(s) claimed to have been given by the Holy Spirit through dream and to have been instructed concerning how it should be interpreted and appropriated for solutions to existential problems.

\section{Phase 5}

The fifth phase of prophetism was begun in the 1990s by indigenous charismatic Ghanaians. It is what Paul Gifford partly referred to as Ghana's New Christianity. ${ }^{19}$ Many Christian programmes and statements were linked with the word "prophetic" or "prophet" in order to attract and maintain members in the church. The word "prophetic" means that members would receive personal prophecies. Apostle Kwamena Ahinful suggests that many members were forcing their pastors to prophesy. ${ }^{20}$ The powerful pastor was the one who prophesied and whenever he/she laid hands on any member, he/she would fall under the anointing.

Although some of the programmes could be labelled as "prophetic", Prophet Bill Hamon noted that some of the programmes were only prophetic in name; the organisers were only "interested in drawing people in to pay large seminar fees to bolster the finances of their church [rather] than to minister prophetically to the

18 Joseph Quayesi-Amakye, Prophetism in Ghana Today: A Study on Trends in Ghanaian Pentecostal Prophetism (n.c.: n.p., 2013), 59-81.

19 Paul Gifford, Ghana's New Christianity: Pentecostalism in a Global African Economy (Bloomington \& Indianapolis: Indiana University Press, 2004), 90-112.

20 Cited in Gifford, Ghana's New Christianity, 90. 
people." ${ }^{21}$ Prophets Bernard Opoku Nsiah, Elisha Salifu Amoako, Isaac Anto, Eric Nana Kwesi Amponsah, and Isaac Owusu-Bempah, among others, were progenitors of this neo-prophetism. They gradually positioned themselves as religious mediators in the Ghanaian society. ${ }^{22}$ Biblical interpretation during this period was the selection of related text(s) in words and acts to form a coherent whole. It is also referred to as interpreting the scriptures based on revelation. Revelation here refers to the leading of the Holy Spirit to select similar text(s) in the Bible to show progression to having better and fast-track solutions. Although it was meant to activate the presence of the Holy Spirit to solve the problems of the audience, the context of the text(s) was not usually considered.

\section{Phase 6}

There was re-emergence of a new form of prophetism in the 2000s in Ghana. The prophetic ministries of some indigenous Ghanaians: Prophet Ebenezer Opambour Yiadom, Bishop Daniel Obinim, Bishop Daniel Bonigas, and Prophet Gabriel Akwasi Sarpong, to mention but a few, can be referred to as the sixth phase of neo-prophetism in Ghana's Christianity. Although many of them claimed to have begun ministry prior to the year 2000, it was obvious that they gained popularity and influence in the 2000s. They were the most criticised phase of neo-prophetism due to: (i) the demand for money from members before accessing their services and the sale of prophylactics at exorbitant rate ${ }^{23}$ (ii) immoral acts; (iii) extravagant lifestyle; (iv) and lack of financial accountability, among others. This phase of prophetism is the loudest due to the use of the media. They have polluted the airwaves with this worldly hermeneutics and are visible on giant bill boards in cities. Many of them conduct services throughout the days of the week coupled with all-night vigils, mostly on Fridays. Scripture text(s) that demand an act by the audience were usually selected and interpreted to commit the audience to respond by giving to the prophet to activate the power in the text(s) and on the prophet to cause a miracle. The context of the audience is key to the interpretive process.

We can deduce from the burgeoning discussion that prophetism in Ghana's Christianity is a "perennial phenomenon" 24 which seeks to replicate or re-enact and maintain biblical prophetism - especially in the book of Acts and in the early church in the context of a socio-religious world-view of Ghana. Each phase emerged at

21 Bill Hamon, Prophets and the Prophetic Movement: God's Prophetic Move Today (Shippensburg, PA: Destiny Image, 1990), 138.

22 Michael Perry Kweku Okyerefo, "The Role of Pentecostal Churches as an Influential Arm of Civil Society in Ghana" in Ghana Social Science Journal Vol. 11, No. 2 (2014), 77-101.

23 Daniel Nii Aboagye Aryeh, "A Study of 'Prophetism in the Gospels and Ga South Municipal Area: A Way Forward for Contemporary Prophetic Ministry in Ghana's Christianity" in Journal of Applied Thought Vol.4, No. 1 (January 2015), 196-221. 
the time when the existing phase seemed to be losing relevance and members were looking for quick and better means of having solutions to their needs. Neo-prophetism usually promises better services than previous or existing prophetic ministries. They have succeeded in making time to meet the pastoral needs of their members. However, some members were not satisfied with the outcome of encountering a prophet. ${ }^{25}$ Their teachings emphasised the work of Satan to frustrate the success of believers and that the power of the Holy Spirit must be engaged through the charisma of a prophet to destroy the works of Satan and his cohorts. ${ }^{26}$ Scripture interpretation process took into consideration the context of the prophet and the audience. It is usually the re-enactment of text(s) in the Bible without exegesis. This is generally considered as being biblical or adhering to biblical principles.

\section{THE MINISTRY OF AGABUS}

Agabus is one of the key prophets in the book of Acts. He is mentioned twice in 11:27-30 and 21:10-14. The nationality of Agabus is not conclusive. Some hold that he was a native of Antioch; ${ }^{27}$ others argue that he hailed from Jerusalem. ${ }^{28}$ These conclusions were influenced by 11:27. We can only say that he was a Christian prophet whose nationality is difficult to ascertain.

The use of $\kappa \alpha \tau \tilde{\eta} \lambda \theta$ ov (come down, go down) as verb, indicative aorist of

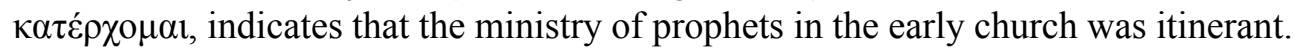
Agabus came from the Church in Jerusalem to Antioch in a group of prophets. It alludes to the Old Testament guild of the "sons of the prophet" who move and prophesy in groups (2 Kings 9:1-3; 5:22-23). It is not clear whether Agabus was the leader of the prophets in this mission, yet, the Holy Spirit used him to minister. The use of $\dot{\varepsilon} \sigma \eta \mu_{\mu \nu \varepsilon v}$ (indicate, signal) as verb, indicative active aorist of $\sigma \eta \mu \alpha i v \omega$ from the root $\sigma \eta \mu$ (to give indication or give intelligent report concerning a situation), suggests that Agabus was not reporting a dream, vision or revelation, or charismatic exegesis of scriptural text, but the declaration or announcement of what has been received through extra-human sensory and believed to be a message from God by the Holy Spirit. Marburg Ernest Fuchs contends that $\sigma \eta \mu \alpha i v \omega$ simply means to signify by the help of the Spirit a future event. ${ }^{29} \Sigma \eta \mu \alpha i v \omega$ is subject to interpretation by the audience or the prophet. It is quite different from issuing out a prophecy to edify,

25 Aryeh, "A Study of 'Prophetism"” JAT, 214.

26 Omenyo and Atiemo, "Claiming Religious Space" GBT, 62-63.

27 Wilber T. Dayton, "Agabus" in Charles F. Pfeiffer, Howard F. Vos and John Rea (Eds.) Wycliffe Bible Dictionary (Peabody, Massachusetts: Hendrickson Publishers, 2008), 30.

28 D. Miall Edwards, “Agabus" in James Orr (Ed.) The International Standard Bible Encyclopaedia Vol. 1 (Grand Rapids, MI: WM. B. Eerdmans Publishing Co., 1949), 69.

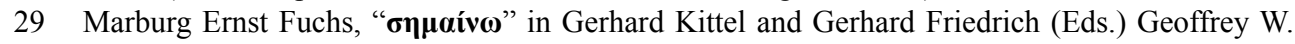
Bromiley (trans.) Theological Dictionary of the New Testament (Grand Rapids, MI: WM. B. Eerdmans Publishing Co.,1982), 264. 


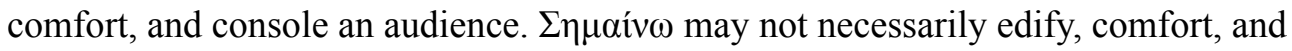
console the audience, but would rather caution them. This phenomenon of prophecy alludes to the Old Testament prophecy which sometimes sounds caution of an impending disaster or judgment of Yahweh on His people.


words by the author (or Agabus), agrees with apocalyptic prophecy. ${ }^{30}$ However, the contribution of relief items for the Christians in Judea (v.29) shows otherwise. It was a famine that did not have any apocalyptic undercurrents. The "whole world" in the text represents the inhabited world, particularly the Roman Empire. Luke records that the prophecy/prediction/forecast of Agabus came to pass during the reign of Claudius (v.28b) in 46 CE, where the River Nile flooded its banks such that most of their farm produce was destroyed, resulting in famine. Nonetheless, historians such as Suetonius and Josephus argue that the flooding of the River Nile was a perennial occurrence and hence it was not an adequate or empirical fulfilment of the prophecy of Agabus. ${ }^{31}$ Others also argue that the famine was due to Sabbath year observation by the Jews. ${ }^{32}$ These indicate that historians do not really accept the famine as the fulfilment of the prophecy of Agabus. It was an attempt to redefine prophecy to mean the prediction/forecasting of an event that is not perennial or could also be caused by other phenomena. It also suggests that since Agabus issued out a sign/indication $(\sigma \eta \mu \alpha i v \omega)$ which may be subject to interpretation, the prophecy was understood differently by people of diverse backgrounds. Above all, the ministry of Agabus provided the avenue for the Christian fraternity to express fellowship by making contributions to mitigate the effect of the famine on Christians in Judea.

Prophet Agabus is again mentioned in 21:10-11 in relation to a prophecy concerning happenings against Paul if he should go to Jerusalem. This alludes to some acts by some Old Testament prophets, such as: (i) Prophet Ahijah tore a new garment into 12 parts and gave 10 parts to Jeroboam as a sign of Yahweh giving 10 tribes of Israel to him (I Kings11:29-32); (ii) Prophet Isaiah took off his sandals and walked barefoot as a prophecy against Egypt and Ethiopia (Isa. 20:2-6); (iii) Jeremiah bought a linen loincloth and put it on his loins as a prophecy against the disobedience of Judah and Jerusalem (Jer. 13:1-11); Agabus also took the waist cloth (belt) of Paul, and tied it around his waist to prophesy that the owner of the cloth (Paul) would be tied in the same manner if he should go to Jerusalem.



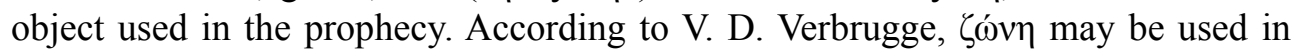

30 Richard J. Dillon, "Acts of the Apostles" in Raymond E. Brown, Joseph A. Fitzmyer and Roland E. Murphy (Eds.) The New Jerome Biblical Commentary (London: Burns and Oates, 1990), 747.

31 Cited in I. Howard Marshall, The Acts of the Apostles: An Introduction and Commentary (Leicester and Grand Rapids, MI: Inter-Varsity Press and William B. Eerdmans Publishing Company, 1980), 204.

32 Cited in I. Howard Marshall, The Acts of the Apostles, 204. 
classical Greek culture to mean girdle or waist belt, made of linen or leather. It can be used to contain money or tie on outer garments as a means of controlling the garment against the wind. ${ }^{33}$ It can be long, such that it can be used to wrap around the body or waist in several rounds. When one puts on a girdle or waist belt, it signifies his/her readiness to depart or undertake a journey.

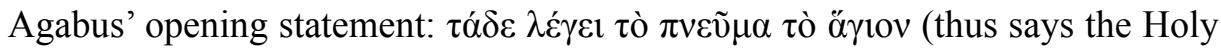
Spirit) indicates that the prophecy to be uttered hailed from the Spirit, not his own imagination. The statement seems to have some similarities with the Old Testament prophetic prefix of "Thus says the Lord". David E. Aune argues that "thus says the Holy Spirit" is the Christian prophet's equivalent of the Old Testament prophets' messenger formula "thus says the Lord". ${ }^{34}$ Conversely, David Hill argues that the prefix to Agabus' prophecy cannot be considered as equivalent to that of the Old Testament prophets' messenger formula, because his prophecy did not come to pass in detail by the standard of Old Testament prophecy. ${ }^{35}$ Hill's assertion suggests that if the prophecy truly comes from God, it will surely come to pass accordingly. Since it did not come to pass word for word, "thus says the Holy Spirit" cannot be a Christianised version of "thus says the Lord". In view of the influence of the LXX in the early church, it is probable that Agabus borrowed and adopted an Old Testament messenger formula phrase of prophecy for attention or to authenticate his prophecy as emanating from the Spirit.

The prophecy may imply that if Paul should desist or postpone his journey to Jerusalem, the danger could have been prevented or minimised. However, it is significant to state that the content of the prophecy did not explicitly state that Paul should not go to Jerusalem. Right from his call to ministry, Paul was made aware of suffering for Christ's sake (Acts 9:15-16). His journey to Jerusalem was at the prompting of the Holy Spirit. He was also aware that persecution and imprisonment awaited him, however, he wished to specifically know what would happen to him in Jerusalem (Act 20:22-24). Hence, the prophecy of Agabus served as an answer to his (Paul's) desire to have foreknowledge concerning specific happenings in Jerusalem, not to prevent him from going to Jerusalem.

From the burgeoning discussions, it is obvious that Agabus' prophecies were characterised by signs and acts. In the first instance, he did not issue out specific prophecy but rather issued a sign which was subject to interpretations by the audience. In the second instance, the prophecy was preceded by an act which was followed by its interpretation by Agabus. In both cases, there were disputes concerning the fulfilment of the prophecies. The prophecies were open to the decision or response

33 Verlyn D. Verbrugge (Ed.) New International Dictionary of New Testament Theology (Grand Rapids: MI: Zondervan Corporation, 2000), 228.

34 David E. Aune, Prophecy in Early Christianity and the Ancient Mediterranean World (Grand Rapids, MI: William B. Eerdmans Publishing Company, 1983), 263-266.

35 David Hill, New Testament Prophecy (London: Marshall, Morgan \& Scott, 1979), 106-108. 
of the audience. It was the believers who decided to contribute and send relief items and services to the Christians in Judea. In the house of Philip, it was the believers who decided to impress on Paul not to go to Jerusalem, nonetheless; Paul insisted and went to Jerusalem.

Although there may be some discrepancies concerning the fulfilment of Agabus' prophecies concerning the famine, and Paul's voyage to Jerusalem, David Oldham argues that the prophecy was fulfilled when Paul reported that: "I was arrested in Jerusalem and handed over to the Romans" (Acts 28:17e). ${ }^{36}$ This assertion ignores the genitive $\dot{\varepsilon} \zeta$ 'I $I \rho \rho \sigma o \lambda \nu \mu \omega v$ (from Jerusalem) (28:17e) and the dative $\dot{\varepsilon} v$ 'I $\varepsilon \rho 0 v \sigma \alpha \lambda \eta \dot{\eta} \mu$ oi

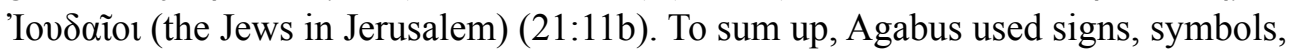
and acts in prophecy.

\section{PROPHET BERNARD OPOKU NSIAH AND HIS PROPHETIC MINISTRY}

The prophetic ministry of Prophet Bernard Opoku Nsiah belonged to the fifth phase of Neo-prophetism in Ghana's Christianity. He was born on June 25, 1962 to Banasco Opoku (father) and Mercy Ampong (mother); both parents hailed from Nyinaheni in Atwema Nponuah district in the Asante region of Ghana. He was the first of six children; three males and three females. ${ }^{37}$ All three males have become prophets. Prophet Opoku Nsiah founded Christian Redemption International Ministry (CRIM) in February 1994, and he is the General Overseer.

\section{Call and early ministry}

Prophet Opoku Nsiah's father died when he was 17 years. Thereafter he embarked on a 40-day fasting and prayer, during which he had an encounter with the Holy Spirit culminating in his call to ministry as a prophet. After the experience, he could now hear the Holy Spirit speak and give him visions concerning the destinies, problems and solutions of people around him. ${ }^{38}$ This suggests that prior to age 17, he was a Christian and knew how to embark on ascetic life in pursuit of a solution to existential needs or empowerment for ministry. The combination of fasting and prayer has been the main religious activity and means for receiving power for ministry by many prophetic ministries in Ghana. Baëta postulates that pioneers of prophetism in Ghana's Christianity usually undertake frequent fastings to aid quick answers to

36 David Oldham, "The Gift of Prophecy and Modern Revivals" in Reformation \& Revival: A Quarterly Journal for Church Leadership Vol. 5, No. 1 (Winter 1996), 111-135 at 125.

37 Bernard Opoku Nsiah, interviewed by author, Sept. 10, 2015 at Christian Redemption International Ministry auditorium at Koforidua, Ghana.

38 Opoku Nsiah, interviewed by author, Sept. 10, 2015. 
prayer. ${ }^{39} \mathrm{He}$ explains that The Church of the Twelve Apostles has two kinds of fasting: (i) abstinence from solid food for seven continuous days, during which water could be taken; (ii) abstinence from solid food and all kinds of drinks for three continuous days. This fasting was generally referred to as dry fasting by Pentecostals. In the Musama Disco Christo Church, particular fasting was prescribed for members while the clergy also had a prescribed fasting each year for empowerment for ministry.

Asamoah-Gyadu observes that for members of the church, fasting enhances the aptitude to overcome temptation and answer to prayers. For the clergy, "the effectiveness of a person's anointing depends on uprightness and enhanced spirituality achieved through fasting, Bible study, and prayer." ${ }^{\text {40 }}$ Prophet Opoku Nsiah's 40-day fasting and prayer seemed to be a replica of Moses', Elijah's, and Jesus' 40-day fasting (Ex, 34:28; 1 Kings 19:8-9; Luke 4:2). It indicates that fasting in Neo-prophetism is the re-enactment of fasting as recorded in the Bible and Jesus' admonishing that some issues need to be overcome by fasting and prayer (Matt. 17:21 KJV). However, it also corresponds to a primal understanding of okomfo (traditional priest), where kom means fasting, hunger, abstinence from food..$^{41}$ Hence skomfo is a traditional priest who occasionally abstains from food in order to foster a close communicative access with the deities. This is not to suggest that a Christian prophet is equivalent to Jkomfo, but to show a point of convergence.

According to Prophet Opoku Nsiah, many of the early prophecies he delivered resulted in arrest and being locked in police cells. This is due to lack of guidance, training, and experience in delivering prophetic messages. For example, he claimed to have prophesied concerning infidelity of a husband in the presence of the wife. The husband denied it leading to a report to the police by the husband that he (Opoku Nsiah) had accused him falsely and wanted to collapse his marriage. Many of these incidents took place when he was a lay preacher of the Assemblies of God (AG), Wamsambre in Asante region between 1979 and 1987. He was later excommunicated from the AG. Notwithstanding, in the 1990s, Rev. Dr Nicholas Npuni, then General Secretary of the AG, decided to run a system similar to that of the Church of Pentecost $(\mathrm{CoP})$. In the CoP, there are institutional prophets who were recognised by the church, and grassroots prophets (who were mainly at prayer camps of the CoP) yet to be recognised. ${ }^{42}$ This system would allow Rev. Dr Npuni to engage Prophet Opoku Nsiah's services as a prophet for members of the AG who needed the

39 Baëta, Prophetism in Ghana, 16, 47-48

40 Asamoah-Gyadu, African Charismatics, 72, 155.

41 John D. K. Ekem, Priesthood in Context: A Study of Priesthood in some Christian and Primal Communities of Ghana its Relevance for Mother-Tongue Biblical Interpretation (Accra: SonLife Press, 2008), 43-45.

42 Quayesi-Amakye, Prophetism in Ghana Today, 59-62, 74-79. 
services of a prophet. Rev. Dr Npuni's novelty was misunderstood and he was also excommunicated from the $\mathrm{AG}$ in $1991 .{ }^{43}$

\section{Ministry work}

Prophet Opoku Nsiah got married to Elizabeth Opoku Nsiah on 26 October 1991. In 1992, he started his own ministry, Christian Redemption Celebration Fellowship in Tema Community 8. It was a fellowship for Christians of all denominations who needed the services of a prophet. Its membership grew to 2800 by 1993. It is significant to reiterate that a majority of the members of Neo-prophetic fellowships were largely drawn mainly from Historic Mission Churches such as the Roman Catholic Church, Presbyterian Church of Ghana, the Methodist Church Ghana, Evangelical Presbyterian Church, who go shopping for miracles and prophecies. ${ }^{44}$ Some of them leave their churches after receiving a solution to their needs or in case of a prolonged solution to their needs or failed expectations. According to Prophet Opoku Nsiah, God spoke to him in 1994 to hand over the leadership of the fellowship to the care of Prophet Del Klomega, one of the associate prophets and to prepare for ministry work in Koforidua in the Eastern region.

Due to lack of funding and inadequate finances to start the fellowship, he took loans from close associates to start the fellowship, with the hope to take offerings from members to pay off the loans. However, his expectation did not materialise, resulting in subsequent reports to and arrest by the Police. ${ }^{45}$ In order to take tithes and other levies to pay off the loans and mobilise money to finance the activities of the ministry, he changed the name to Christian Redemption International Ministry (CRIM) in 1994. He moved to Koforidua in 2004 and started CRIM's headquarters, which now has branches in Accra, Tema, and other parts of Ghana.

\section{Agabus Prophetic School (training school for would-be prophets)}

According to Prophet Opoku Nsiah, God spoke to him concerning the training of prophets for ministry. Hence, in 1999, he began Agabus Prophetic School to train persons who felt called by God to be a prophet. Academic qualifications were not necessarily a requirement. Training would be by mentorship. Trainees were expected to come and pray very often at the prayer camp located on the same premises of the church in Koforidua.

Mentorship training means to understudy a senior prophet with the desire and hope to be impacted by the charismatic gifts of the mentor. In Agabus Prophetic

43 Opoku Nsiah, interviewed by author, Sept. 10, 2015.

44 Asamoah-Gyadu, African Charismatics, 117.

45 Opoku Nsiah, interviewed by author, Sept. 10, 2015. 
School, there was no fixed duration and no fee was charged. Mentees serve the mentor and his or her ministry during training instead of paying fees. Upon completion and graduation, many mentees were expected to function just like the mentor. Hence it perpetuated the ministry philosophy and aspirations of the mentor, thereby subjecting ministry aspirations of mentees. R. Bogere holds that mentorship is the main form of training into ministry in both the Old and New Testaments. ${ }^{46}$ Therefore, Prophet Opoku Nsiah was deemed to be implementing biblical concepts of training. However, in this form of training, priority is given to the anointing of the Holy Spirit (spirituality) over academic (intellectualism), thereby creating tension and polarity of "academic versus spiritual, and practical versus theoretical." ${ }^{47}$ We can argue that in view of globalisation, the challenge that other religions pose to Christianity and the desire for religion to provide answers to existential needs of adherents, there is a need for the anointing and academic to play a complementary role rather than contradictory.

In 2014, Prophet Opoku Nsiah realised that basic schools in the community (in which the Church was situated in Koforidua) were inadequate; pupils would have to walk long distances to school. As a social service, he expanded and converted the structures used by Agabus Prophetic School into Lizben Educational Complex, a basic school for the community where fees charged were lower than other private basic schools. A new site was being sought for the building of prayer camp which would also serve as venue for Agabus Prophetic School. The term "Lizben" was the amalgamation of his wife's name, Elizabeth and his name Bernard. Although his wife had a Bachelor's degree in educational psychology, it also showed the active involvement by the spouses of General Overseers in ministry.

\section{PROPHET BERNARD OPOKU NSIAH AND CONTEMPORARY PROPHETIC MINISTRY}

Prophet Opoku Nsiah was worried concerning reports in the media about the moral lives and ritual practices of some contemporary prophets. Contemporary prophets refer to the sixth phase of prophetism in Ghana's Christianity, as discussed above. According to Nsiah, Christian prophetism is fuelled by prayer, passion for Christ, and morality. Since the beginning of the year 2000, many prophets who emerged have replaced these cherished virtues with greediness and therefore "we are in prophetic apostasy". ${ }^{48}$ Prophet Opoku Nsiah has trained many prophets, and in that regard he

46 Richard Bogere, "Kampala School of Theology: A Case Study in the Development of a Holistic Training Model" in PneumAfrica Journal 1:1 (2013), 35-52.

47 Veli-Matti Kärkäinnen, “'Epistemology, Ethos and Environment': In Search of a Theology of Pentecostal Theological Education"' in The Pentecostal Educator Vol. 1, No. 1, (Fall 2014), 22 36.

48 Opoku Nsiah, interviewed by author, Sept. 10, 2015. 
is commonly referred to as a senior prophet or prophetic Papa. His plan for the future of prophetic ministry in Ghana is to have a large prayer camp that can house about one thousand students for Agabus Prophetic School in order to correct the wrongs in prophetic ministry and minister to the needs of members.

\section{PRESENTATION OF FINDINGS}

The discussion of the research findings shows that:

- Many of the leaders of prophetic ministries in Ghana's Christianity were not theologically trained concerning biblical interpretation. Hence, their interpretation of scripture does not follow any scientific and philosophical system or ideology.

- The history shows that scripture interpretation in prophetic ministries was a kind of re-enactment of favourite scripture text(s) that consider the context of the prophet and the audience in the interpretive process, directed at re-enacting the power in scripture to solve problems.

- Their system of hermeneutics is to find support for their ministry practices in the Bible. In other words, they try to find proof and authentication for their presuppositions to be referred to as Bible-believing and practising Christians. It is presumed that the Bible was written with the 21 st century Ghanaian prophetic Christian in mind.

- It has the advantage of referring to the Bible as a living document for contemporary audiences and times.

\section{Theological education and biblical interpretation by prophetic ministries}

Theological education is considered by some prophets as anti-spiritual. As a strand of Pentecostal Christianity, K. Warrington observes that Pentecostals are not concerned with creeds or theological and doctrinal formulations. They are driven by the sheer desire to be biblical; that is, trying to conform to what is recorded on the pages of the Bible, hence the early theological institutions or seminaries of Pentecostals were called Bible Schools. ${ }^{49}$ This indicates that one's experiences are an influential element in biblical hermeneutics. In other words, the need of the moment is central to how one interprets the Bible.

The Bible is available for use by theologically trained persons and the ordinary Christian and non-Christian reader. However, J. S. Pobee and J. N. K. Kudadjie

49 Keith Warrington, Pentecostal Theology: A Theology of Encounter (London and New York: T \& T Clark, 2008), 180-181. 
state the purpose of theological education as to: “...conscientize, mobilise and motivate the people at the grass-roots level for social change, and to work with them in identifying their needs, setting their own priorities and standards and recognising the resources that are available to them for use in development." ${ }^{.0}$ The assertion places the motivation for theological education for prophets at the door step of theological institutions and trained theologians. Theological institutions ought to develop curricula that cater for both the academic and spiritual needs of prophets. There should be courses geared at fostering close relationships between the students and the Holy Spirit, and the cessationist approach of many accredited theological institutions in Ghana needs to be softened. This has fuelled a popular notion among many prophets that formal theological education does not support spiritual formation. In that regard, they prefer to go to Christian sacred places like mountains and prayer camps, praying for long periods, or being mentored by a senior prophet in order to receive the anointing of the Spirit to begin ministry. The mentorship training emphasises mimicking characters in the Bible, just as Elisha's desire to receive a double portion of Elijah's anointing, and not any other prophet to be his mentor.

Since many of the prophets were not theologically trained, they were not able to handle the exegetical component of the hermeneutical process. Hence, they practise a kind of hermeneutics of re-enacting biblical text(s) without recourse to what it meant to the "original" audience. Phase 3 of prophetism in Ghana's Christianity attempted to exegete text(s) before contextualisation and appropriation; nonetheless, they were too lexical - such that the context of the text(s) was ignored. Phase 5 also attempted to do exegesis in order to locate the texts in their context, but they picked parallel text(s) from different contexts to exegete the text(s). In other words, the texts were exegeted not in their own context. All these indicate the willingness of prophets to interpret the Bible and make it relevant to their audiences. The biblical document is an uncompleted story until it is contextualised and appropriated by people in a particular context. ${ }^{51}$ Interpreting Joshua 6 , the audiences were made to believe that God is able to speak to the prophet to undertake an act that will manifest the power of God. Just as Joshua asked the priests to go round the walls of Jericho while blowing rams' horns, which led to the collapse of the wall and victory for the Israelites, the story is re-enacted by asking the audience to go around their individual plastic chairs in the Church amidst shouting to pull down barriers and problems.

50 Cited in Emmanuel Asante, "The Relevance of Theological Education in the 21st Century" in Trinity Journal of Church and Theology Vol. XIII No. 03 (July 2003), 77-82.

51 Musa W. Dube, "Boundaries and Bridges: Journeys of a Postcolonial Feminist in Biblical Studies" in Journal of the European Society of Women in Theological Research Vol. 22 (2014) 139-156 at 142-143. 


\section{AGABUS AND OPOKU NSIAH}

Prophet Opoku Nsiah's asserted that: "I minister with signs, symbols, tokens, types, colours just like Agabus" 52 (in Acts 11:28; 21:10), which is an attempt to be biblical in outlook. Prophet Opoku Nsiah's allusion to the ministry of Agabus is not in minute details of prophecies. Although he often gives minute details, his interest is in fulfilment of prophecies issued and to be in agreement with prophetism in the New Testament. Therefore, the establishment of the Agabus Prophetic School is to re-enact the Agabus events in the book of Acts and to raise prophets just like Agabus in the Ghanaian context. This would eventually culminate into Agabus' prophetic tradition in Ghana.

\section{CONCLUSION}

In this paper, I attempted to discuss the history of prophetism in Ghana's Christianity, beginning from 1914 to 2016 . The purpose is to identify the hermeneutical principle used in each phase. It was realised that all six phases of prophetism in Ghana's Christianity employed a kind of "re-enactment hermeneutics" without exegesis of the text in its socio-historical context. It was directed at re-activation of an implicit power in the text(s) to solve existential needs and give prophetic directions into the future. This type of hermeneutics influenced the assertion of Prophet Opoku Nsiah to argue that his ministry is a replica of Agabus, because they both minister using signs, symbols, and tokens, among others.

Although many prophets were not theologically trained, the neglect of exegesis is due to its passive nature. Prophets would like to interpret the Bible to have effect on the present and the future. Notwithstanding, I propose that the hermeneutics of re-enacting biblical text(s) and concepts to solve existential needs and to have a futuristic/prophetic/predictive effect, must consist of exegesis, contextualisation, and appropriation. The exegesis must bring out the religio-cultural settings of the text(s), and the literary type used. The contextualisation must show and relate the text(s) to the Ghanaian religio-cultural settings; and this appropriation will lead prophetic acts or rituals to solve existential problems and give direction into the future. This will better consolidate the faith of the members in the knowledge of scripture and in the anointing of the prophet.

\section{REFERENCES}

Agbeti, J. K. 1991. "The Need for Scholarship in the Training for the Christian Ministry." Trinity Journal of Church and Theology, 1 (1) (June): 25-34.

52 Opoku Nsiah, interviewed by author, Sept. 10, 2015. 
Amevenku, Frederick Mawusi. 2014. "Mother-Tongue Biblical Interpretation and the Future of African Instituted Christianity in Ghana." Trinity Journal of Church and Theology, 18 (1) (March): 132-148.

Aryeh, Daniel Nii Aboagye. 2015. "Socio-Rhetorical Exegesis of 1 Corinthians 14:26-40 for an Understanding of $\pi \rho \circ \varphi \eta \tau\rceil$ in Pauline Corpus and its Implications for Contemporary Prophetic Ministry in Ghana.” A Master of Theology thesis submitted to Trinity Theological Seminary, Legon Ghana.

Aryeh, Daniel Nii Aboagye. 2015. Urban Public Space Evangelism: Evangelism in Market Places in Ghana. Saarbrücken: LAP Lambert Academic Publishing.

Asamoah-Gyadu, J. Kwabena .2010. “"Called to Make a Difference': Theological Education and Mission in the Twenty-first Century.” Ogbomosho Journal of Theology, XV (2): 1-16.

Asamoah-Gyadu, J. Kwabena. 2009. "Theological Education and Religious Pluralism in Ghana." In Christianity, Mission and Ecumenism in Ghana: Essays in Honour of Robert K. AboagyeMensah, edited by J. Kwabena Asamoah-Gyadu. Accra: Asempa Publishers.

Asamoah-Gyadu, J. Kwabena. 2005. African Charismatics: Current Development within Independent Indigenous Pentecostalism in Ghana. Leiden: Koninklijke Brill NV.

Asamoah-Gyadu, J. Kwabena. 2013. Contemporary Pentecostal Christianity: Interpretations from an African Context. Oxford: Regnum Books International.

Asamoah-Gyadu, J. Kwabena. 2015. Sighs and Signs of the Spirit: Ghanaian Perspectives on Pentecostalism and Renewal in Africa. Oxford: Regnum Books International.

Asante, Emmanuel. 2003. "The Relevance of Theological Education in the 21st Century." Trinity Journal of Church and Theology, XIII (3) (July): 77-82.

Aune, David E. 1983. Prophecy in Early Christianity and the Ancient Mediterranean World. Grand Rapids, MI: William B. Eerdmans Publishing Company.

Bogere, Richard. 2013. "Kamala School of Theology: A Case Study in the Development of a Holistic Training Model.” PneumAfrica Journal, 1:1 35-52.

Brodie, Robert. 2011. "The Anointing or Theological Training? A Pentecostal Dilemma." Conspectus, 11 (1): 47-65. 
Dayton, Wilber T. 2008. “Agabus.” In Wycliffe Bible Dictionary, edited by Charles F. Pfeiffer, Howard F. Vos and John Rea. Peabody, Massachusetts: Hendrickson Publishers.

Dillon, Richard J. 1990. “Acts of the Apostles.” In The New Jerome Biblical Commentary, edited by Raymond E. Brown, Joseph A. Fitzmyer and Roland E. Murphy. London: Burns and Oates.

Dube, Musa W. 2014. "Boundaries and Bridges: Journeys of a Postcolonial Feminist in Biblical Studies." Journal of the European Society of Women in Theological Research, 22: 139-156.

Easter, John L. 2013. "Under the Mango Tree: Pentecostal Leadership Training in Africa." PneumAfrica Journal, 1 (1): 1-22.

Edwards, D. Miall. 1949. "Agabus" in James Orr (Ed.) The International Standard Bible Encyclopaedia (volume 1). Grand Rapids, MI: WM. B. Eerdmans Publishing Co.

Ekem, John D. K. 2008. Priesthood in Context: A Study of Priesthood in some Christian and Primal Communities of Ghana its Relevance for Mother-Tongue Biblical Interpretation. Accra: SonLife Press.

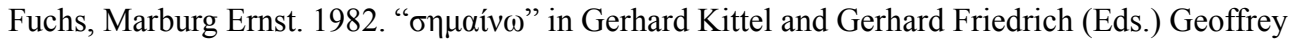
W. Bromiley (trans.) Theological Dictionary of the New Testament. Grand Rapids, MI: WM. B. Eerdmans Publishing Co.

Grey, Jacqueline. 2008. “The Experience of a Woman as Pentecostal Academic.” Asian Journal of Pentecostal Studies, 11 (1): 94-89.

Grudem, Wayne. 2000. Systematic Theology: An Introduction to Biblical Doctrine. Leicester: InterVarsity Press.

Hill, David. 1979. New Testament Prophecy. London: Marshall, Morgan \& Scott.

Joshua, Stephen Muoki. 2006. “The interface Between 'Missionary' and 'National' Theological Education in the Free Pentecostal Fellowship in Kenya: A Historical Perspective." Studia Historiae Ecclesiasticae, XXXII(3): 173-191.

Kärkkäinen, Veli-Matti. 2014. “"Epistemology, Ethos, and Environment': In Search of a Theology of Pentecostal Theological Education.” The Pentecostal Educator, 1 (1) (Fall) 22-36.

Lewis, Paul W. 2008. "Why Have Scholars Left Classical Pentecostal Denominations." Asian Journal of Pentecostal Studies, 11 (1-2): 69-86. 
Mante, Joseph Obiri Yeboah. 1995. An Outline of Some Basic Principles of Christian Spirituality. Accra: Webson Ventures.

Marshall, I. Howard. 1980. The Acts of the Apostles: An Introduction and Commentary. Leicester and Grand Rapids, MI: Inter-Varsity Press and William B. Eerdmans Publishing Company.

Nenty. H. Johnson and Biao, Idowu. 2013. "The Professor within the Context of African Universities." Institute of Africa Studies, University of Ghana, Contemporary Journal of African Studies, 1 (2): 1-20.

Oladejo, Olusayo Bosun. 2011. "Prophetic Guild in the Old Testament as a Paradigm for SocioPolitical Transformation in Africa." Ogbomosho Journal of Theology, XVI (3): 115-136.

Oldham, David. 1996. "The Gift of Prophecy and Modern Revivals." Reformation \& Revival: A Quarterly Journal for Church Leadership, 5 (1) (Winter): 111-135.

Omenyo, Cephas N. 2008. "The Spirit-Filled Goes to School: Theological education in African Pentecostalism." Ogbomosho Journal of Theology, XII (2): 41-57.

Opoku, Kofi Asare.1978. West African Traditional Religion. Accra: FEP International.

Sarpong, Peter K. 2002. Peoples Differ: An Approach to Inculturation in Evangelization. Accra: Sub-Saharan Publishers.

Tate, W. Randolph. 2012. Handbook for Biblical Interpretation: An Essential Guide to Methods, Terms, and Concepts. Grand Rapids, Michigan: Baker Academic.

Verbrugge, Verlyn D. (Ed.). 2000. New International Dictionary of New Testament Theology. Grand Rapids: MI: Zondervan Corporation.

Walls, Andrew F. 2011. "Spirituality and Theological Education." Ogbomosho Journal of Theology, XVI (3): 1-12.

Warrington, Keith. 2008. Pentecostal Theology: A Theology of Encounter. London and New York: $\mathrm{T} \& \mathrm{~T}$ Clark.

Whitt, Irving A. 2013. "Contextualization Training for Pentecostal Leaders in Africa: Retrospect and Prospect." PneumAfrica Journal, 1 (1): 23-34.

Wilkinson, Michael and Althouse, Peter. 2012. "Pentecostalism as Lived Religion." Canadian Journal of Pentecostal-Charismatic Christianity, 3: i-iv. 